\title{
Developments in Other Haematological Malignancies: Other Lymphoid Malignancies
}

\author{
Paolo Corradini and Lorenz Trümper
}

Peripheral T cell lymphomas comprise a heterogeneous group of rare diseases, representing 10-15\% of all non-Hodgkin lymphomas (NHLs). Upfront treatment for peripheral $\mathrm{T}$ cell lymphoma (pTNHL) includes CHOP-like (cyclophosphamide, adriamycin, vincristine, prednisone) multiagent chemotherapy with or without etoposide, followed by stem cell transplantation as consolidation in responsive fit patients. This approach induces durable long-term remission in approximately $40 \%$ of cases; early refractoriness during induction occurs in approximately $25 \%$ of patients, with the remaining patients typically relapsing within 24 months. With the exception of patients with anaplastic large cell lymphomas who are eligible to receive brentuximab vedotin, there is no standard of care in the relapse setting. In patients not eligible to receive high-dose chemotherapy followed by allogeneic stem cell transplantation, the prognosis is dismal.

CAR-T cells have shown impressive results in relapsed/refractory B-cell lymphoma and are currently under investigation in T cell lymphomas.

\section{Target Antigens}

The choice of the appropriate antigen constitutes the main challenge in targeting $\mathrm{T}$ cell malignancies using CAR-T cells. Many target antigens are expressed by both physiological T cells and engineered CAR-T cells (Tables 17.1 and 17.2).

\footnotetext{
P. Corradini

Divisione di Ematologia, Fondazione IRCCS Istituto Nazionale dei Tumori di Milano, Università degli Studi di Milano, Milan, Italy e-mail: paolo.corradini@unimi.it

L. Trümper $(\bowtie)$

Department of Hematology and Oncology, Georg-August University Göttingen,

Göttingen, Germany

e-mail: lorenz.truemper@med.uni-goettingen.de 
Table 17.1 Pan-T cell antigens

\begin{tabular}{l|l}
\hline CD5 & Expression in T cells, thymocytes, B-1 cells, and T cell malignancies: \\
& $90 \%$ T-ALL/Ly \\
& $85 \%$ PTCL-nos \\
& $96 \%$ AITL \\
& $26-32 \%$ ALCL \\
& $36 \%$ NK-T \\
& $85 \%$ ATLL \\
& $91 \%$ CTCL \\
& Expression in T cells, thymocytes, NK cells, and T cell malignancies: \\
& $95 \%$ T-ALL/Ly \\
& $50 \%$ PTCL-nos \\
& $57 \%$ AITL \\
& $32-54 \%$ ALCL \\
& $79 \%$ NK-T \\
& $25 \%$ ATLL \\
& $18 \%$ CTCL \\
\hline
\end{tabular}

Table 17.2 Antigens with restricted expression

\begin{tabular}{l|l}
\hline CD30 & Expression in activated T and B cells and in T cell malignancies: \\
& $17 \%$ T-ALL/Ly \\
& $16 \%$ PTCL-nos \\
& $32-50 \%$ AITL \\
& $93 \%$ ALCL \\
& $64 \%$ NK-T \\
& $39 \%$ ATLL \\
& $18 \%$ CTCL \\
\hline TRBC1 & Expression in T cells and in T cell malignancies: \\
& $7-11 \%$ T-ALL/Ly \\
& $27 \%$ PTCL-nos \\
& $34 \%$ AITL \\
& $25 \%$ ALCL \\
\hline
\end{tabular}

Therefore, this shared antigen expression can potentially result in the following issues:

- A fratricide effect on CAR-T cells.

- Ablation of physiological donor T cells after CAR-T cell infusion, leading to deep and/or long-lasting immune deficiency and T cell aplasia.

\section{CAR-T Development in T Cell Malignancies}

Some experimentally engineered CAR-T cell products targeting CD5, CD7, CD30, and TRBC1 (T cell receptor beta chain 1) have been tested (Table 17.3). 
Table 17.3 CAR-T cells targeting $\mathrm{T}$ lymphocyte antigens

\begin{tabular}{|c|c|}
\hline $\begin{array}{l}\text { CAR-T cells } \\
\text { targeting } \\
\text { CD5 }\end{array}$ & $\begin{array}{l}\text { Mamonkin et al. (Blood 2015), preclinical experience: } \\
\text { - CD5 CAR-T cells eliminate malignant T-ALL/Ly lines in vitro and inhibit } \\
\text { disease progression in xenograft mouse models } \\
\text { - Second-generation CD5 CAR with a CD28 costimulatory domain: With the } \\
\text { loss of CD5 expression on the surface of T cells, CD5 CAR-T cells become } \\
\text { resistant to fratricide } \\
\text { Hill et al. (Blood 2019), phase I dose escalation study, MAGENTA trial: } \\
\text { - } 9 \text { patients enrolled (4 T-ALL, } 5 \text { T-NHL) } \\
\text { - CD5 CAR-T cells are safe and can induce clinical responses ( } 3 \text { patients in } \\
\text { complete response) in heavily pretreated relapsed/refractory T-ALL and } \\
\text { T-NHL, without inducing T cell aplasia }\end{array}$ \\
\hline $\begin{array}{l}\text { CAR-T cells } \\
\text { targeting } \\
\text { CD7 }\end{array}$ & $\begin{array}{l}\text { Gomes-Silva et al. (Blood 2017), preclinical models of T cell malignancies: } \\
\text { - Fulminant fratricide precluding expansion of CAR-T cells } \\
\text { - Abrogation of CD7 expression from the cell surface shows potential activity } \\
\text { A phase I study (CRIMSON trial) has been designed at Baylor College of } \\
\text { Medicine but is not yet recruiting }\end{array}$ \\
\hline $\begin{array}{l}\text { CAR-T cells } \\
\text { targeting } \\
\text { TRBC1 }\end{array}$ & $\begin{array}{l}\text { Maciocia et al. (Nat Med 2017), preclinical studies: } \\
\text { - CAR-T cells targeting TRBC1 are able to specifically eliminate malignant T } \\
\text { cell lines expressing TRBC1 } \\
\text { - TRBC1 CAR-T cells cannot target normal TRBC2-positive T cells } \\
\text { A phase I/II study (AUTO4) coordinated by the University College of London } \\
\text { is a single-arm trial evaluating the safety and clinical activity of a CAR-T cell } \\
\text { targeting TRBC1 in patients with relapsed/refractory TRBC1-positive T cell } \\
\text { lymphomas }\end{array}$ \\
\hline $\begin{array}{l}\text { CAR-T cells } \\
\text { targeting } \\
\text { CD30 }\end{array}$ & $\begin{array}{l}\text { Dotti et al. (Immunol Rev. 2014), preclinical studies: } \\
\text { - CAR-T cells targeting CD30 generate tumour-specific T cells in patients with } \\
\text { Hodgkin and anaplastic T cell lymphomas } \\
\text { - Tumour recognition by CD30 CAR-T cells is MHC-unrestricted } \\
\text { - CAR-T cells targeting CD30 potentially overcome tumour escape } \\
\text { Several small clinical trials are being reported; some studies are ongoing and } \\
\text { recruiting: } \\
\text { - Two CAR-T constructs are under investigation, one CAR-T cell with the } \\
\text { antigen-binding domain of the anti-CD30 and ant-CD28 costimulatory } \\
\text { domain and another CAR-T cell targeting CD30 and 4-1BB as a } \\
\text { costimulatory domain } \\
\text { - In the Ramos et al. phase I study, } 9 \text { patients with relapsed/refractory Hodgkin } \\
\text { and EBV-negative, CD30-positive ALCL have been treated; results are } \\
\text { promising, with } 1 \text { patient in complete remission and } 3 \text { in stable disease, } \\
\text { without relevant toxicities } \\
\text { - Wang et al. enrolled } 18 \text { patients (17 Hodgkin, one ALCL); seven patients } \\
\text { achieved a partial response and six achieved stable disease, with limited } \\
\text { acute toxicities but an increased risk of infections } \\
\text { - Grover et al. enrolled } 24 \text { patients (Hodgkin, ALCL, EATL, and Sezary } \\
\text { syndrome) in a phase Ib/II study with anti-CD30 CAR-T cells, which } \\
\text { demonstrated early clinical effects and good tolerability and safety } \\
\text { - A phase I study is ongoing at the National Cancer Institute to assess safety } \\
\text { and feasibility in advanced CD30-positive ALCL and PTCL-NOS }\end{array}$ \\
\hline
\end{tabular}




\section{Key Points}

- Target antigens are expressed by normal $\mathrm{T}$ cells, malignant $\mathrm{T}$ cells, and engineered CAR-T cells.

- Therefore, the major concern for targeting T cell malignancies with CAR-T cells is a fratricide effect.

- A second major issue is the ablation of normal T cells after CAR-T cell infusion, potentially causing severe and/or long-lasting immune deficiency and $\mathrm{T}$ cell aplasia.

- Currently, the most promising constructs are CAR-T cells targeting CD30.

- Phase I and II studies are ongoing in T cell malignancies and Hodgkin lymphoma, thus far demonstrating feasibility, tolerability, and potential for clinical efficacy.

\section{Bibliography}

Dotti G, Gottschalk S, Savoldo B, et al. Design and development of therapies using chimeric antigen receptor-expressing T cells. Immunol Rev. 2014;257(1):107-26.

Foster C, Kuruvilla J. Treatment approaches in relapsed or refractory peripheral T-cell lymphomas. F1000Research. 2020;9(Faculty Rev):1091.

Gomes-Silva D, Srinivasan M, Sharma S, et al. CD7-edited T cells expressing a CD7-specific CAR for the therapy of T-cell malignancies. Blood. 2017;130:285-96.

Grover NS, Park SI, Ivanova A, et al. A phase Ib/II study of anti-CD30 chimeric antigen receptor $\mathrm{T}$ cells for relapsed/refractory CD30+ lymphomas. Biol Blood Marrow Transplant. 2019;25(3):S66.

Hill LC, Rouce RH, Smith TS, et al. Safety and anti-tumor activity of CD5 CAR-T cells in patients with relapsed/refractory T-cell malignancies. Blood. 2019;134(S1):199.

Maciocia PM, Wawrzyniecka PA, Philip B, et al. Targeting the T cell receptor $\beta$-chain constant region for immunotherapy of T cell malignancies. Nat Med. 2017;23(12):1416-23.

Mamonkin M, Rouce RH, Tashiro H, et al. A T-cell directed chimeric antigen receptor for the selective treatment of T-cell malignancies. Blood. 2015;126:983-92.

Ramos CA, Ballard B, Zhang H, et al. Clinical and immunological responses after CD30-specific chimeric antigen receptor-redirected lymphocytes. J Clin Invest. 2017;127(9):3462-71.

Rogers AM, Brammer JE. Hematopoietic cell transplantation and adoptive cell therapy in peripheral T cell lymphoma. Curr Hematol Malig Rep. 2020;15:316-32.

Sherer LD, Brenner MK, Mamonkin M. Chimeric antigen receptors for T-cell malignancies. Front Oncol. 2019;9(126):1-10.

Vose J, Armitage J, Weisenburger D. International peripheral T-cell and natural killer/T-cell lymphoma study: pathology findings and clinical outcomes. J Clin Oncol. 2008;26(25):4124-30.

Wang CM, Wu ZQ, Wang Y, et al. Autologous T cells expressing CD30 chimeric antigen receptors for relapsed or refractory Hodgkin lymphoma: an open-label phase I trial. Clin Cancer Res. 2017;23(5):1156-66. 
Open Access This chapter is licensed under the terms of the Creative Commons Attribution 4.0 International License (http://creativecommons.org/licenses/by/4.0/), which permits use, sharing, adaptation, distribution and reproduction in any medium or format, as long as you give appropriate credit to the original author(s) and the source, provide a link to the Creative Commons license and indicate if changes were made.

The images or other third party material in this chapter are included in the chapter's Creative Commons license, unless indicated otherwise in a credit line to the material. If material is not included in the chapter's Creative Commons license and your intended use is not permitted by statutory regulation or exceeds the permitted use, you will need to obtain permission directly from the copyright holder.

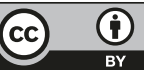

